\title{
Palaeoseismicity in relation to basin tectonics as revealed from soft-sediment deformation structures of the Lower Triassic Panchet formation, Raniganj basin (Damodar valley), eastern India
}

\author{
AbHik Kundu ${ }^{1, *}$, Bapi Goswami ${ }^{2, * *}$, PATrick G ERIKSSON ${ }^{3, \dagger}$ \\ and ABHiJit CHAKRABORTY ${ }^{4, \ddagger}$ \\ ${ }^{1}$ Department of Geology, Asutosh College, 92, S.P. Mukherjee Road, Kolkata 700 026, India. \\ ${ }^{2}$ Department of Geology, University of Calcutta, 35, Ballygunge Circular Road, Kolkata 700 029, India. \\ ${ }^{3}$ Department of Geology, University of Pretoria, Pretoria 0002, South Africa. \\ ${ }^{4}$ Department of Geology, Jogamaya Devi College, 92, S.P. Mukherjee Road, Kolkata 700 026, India. \\ *e-mail: kundu.abhik@gmail.com \\ **e-mail: bapigoswami69@yahoo.co.in \\ $\dagger$ †-mail: pat.eriksson@up.ac.za \\ ‡e-mail: chakra_bhiji@yahoo.co.in
}

The Raniganj basin in the Damodar valley of eastern India is located within the riftogenic Gondwana Master-Basin. The fluvio-lacustrine deposits of the Lower Triassic Panchet formation of the Damodar valley in the study area preserve various soft-sediment deformation structures such as slump folds, convolute laminae, flame structures, dish-and-pillar structures, sandstone dykes, pseudonodules and syn-sedimentary faults. Although such soft-sediment deformation structures maybe formed by various processes, in the present area the association of these structures, their relation to the adjacent sedimentary rocks and the tectonic and depositional setting of the formation suggest that these structures are seismogenic. Movements along the basin margin and the intra-basinal faults and resultant seismicity with moderate magnitude (2-5 on Richter scale) are thought to have been responsible for the soft-sediment deformations.

\section{Introduction}

The varieties of sedimentary structures that form in semi-liquefied sediments when they lose their strength are designated as the soft-sediment deformation structures (e.g., Lowe 1975). Softsediment deformation structures in clastic sediments reflect deformation that occurs in still unlithified sediments or in sedimentary rocks that had not yet undergone complete lithification before the deformation started (Van Loon 2009). The origin of soft-sediment deformation structures remains an often contentious question.
Owen (1995) found that either sedimentary or tectonic processes may control the formation of most of these deformation structures. It remains difficult to decipher whether the soft-sediment deformation structures in seismically-induced mass-flow deposits are formed by the direct or indirect effect of a seismic event (Seilacher 1984). The different degree of compaction of sediments is one of the most important controls on softsediment deformation (Mazumder et al 2009). Rapid deposition, differential loading in adjacent parts of the sediment, and slope and gravity controlled density currents are other main

Keywords. Soft-sediment deformation structures; seismites; Panchet formation; Lower Triassic. 
causes for soft-sediment deformation (Bowman et al 2004).

Seismic activity may result in the deformation of unconsolidated sediments leading to liquefaction and fluidization (Obermeier 1996; Sukhija et al 2003; Guccione 2005). These 'seismites' (Seilacher 1969) or 'seismically induced soft-sediment deformation structures' (sensu Ricci Lucchi 1995) are important indicators of syn-sedimentation earthquake activity and can throw light on the tectonic setting of the depositional basin (Seth et al 1990). To help understand whether soft-sediment deformation structures are sedimentation-controlled or seismically-induced, a combination of various field criteria is prescribed by different authors (e.g., Sims 1973, 1975; Obermeier 1996; Jones and Omoto 2000; Bose et al 2001; Wheeler 2002).

In this paper, we document the suite of softsediment deformation structures from an extensive 1.5 to $2.0 \mathrm{~m}$ thick sand-mud heterolithic horizon, extending over a $9 \mathrm{~km}^{2}$ area within the Lower Triassic Panchet formation, in the immediate vicinity and surrounds of Banspetali village, within the Raniganj basin of the Damodar valley (figure 1). Additionally, the spatial relationships of these structures are carefully examined and interpreted to understand the genesis of these structures better, and to correlate their inferred genesis with basin configuration and its inferred tectonic setting.

\section{Geological setting}

\subsection{Tectonic framework of Gondwana basins}

The Indian plate is thought to be an assembly of microcontinents, sutured along Proterozoic mobile belts (Biswas 1999 and references therein). These belts acted as zones of rift propagation, and reactivation of palaeo-sutures and graben formation along these sutures is inferred to have generated the intra-cratonic Gondwana basins (Mitra 1994; Tewari and Casshyap 1996). In the Permo-Triassic, before separation of the east and the west Gondwana terrains, intra-continental extensional tectonics was active and this was responsible for the formation of the sag basins of the Gondwana period; most of the continental Gondwana sediments in India were deposited during this extensional regime (Biswas 1999). These Gondwana sedimentary successions overlie Late Archaean or Middle-to-Late Proterozoic basement rocks and are flanked by regional dislocation zones (Narula et al 2000). Sediment accumulations of great thickness reflect repeated syn-sedimentary subsidence events and dislocation along the intra-basinal faults and asymmetric basin-fills with greater thickness towards one of the basin margin fault systems indicate faulting-induced subsidence to provide the necessary accommodation (Ramanamurthy and Parthasarathy 1988; Chakraborty and Ghosh 2005 and references therein; Veevers and Tewari 1995; Mishra et al 1999).

The continental Gondwana sedimentary successions of India are exposed in eastern, central and south-central parts of the country, and the basins are mainly aligned along three river valleys: the Narmada-Son-Damodar, the Pranhita-Godavari and the Mahanadi (figure 1). These three Permianto Jurassic-aged riftogenic continental basins filled with Gondwana sediments converge to meet at the Satpura area in central India (Narain 1994; Chakraborty and Ghosh 2005).

The Raniganj basin (figure 1), the easternmost part of the Damodar valley is a semi-elliptical, elongated basin, situated between Damodar and Ajoy rivers (Ghosh 2002). The sedimentary fill of the Raniganj basin comprises a Gondwana succession from the Lower Gondwana Group (Permian) to the Upper Gondwana Group (Triassic to Lower Cretaceous) (Gee 1932; Ghosh 2002). The southern boundary of the basin is $\mathrm{E}-\mathrm{W}$ trending, steep down-displacement dip-slip fault zone, indicative of an extensional tectonic setting (Gibbs 1984), which led to a half-graben geometry with accumulation of greater thickness of sediment towards the south (Ghosh 2002). Transverse normal faults, regarded as transfer faults (Gibbs 1984), are distributed along the basin margin and have affected the contact of the Gondwana sedimentary successions with the basement rocks. These faults have dislocated the basin boundary fault and are thus younger and were probably initiated after the beginning of sedimentation. Conjugate sets of intrabasinal normal faults transverse to the basinal trend are common, and have truncated the entire Gondwana sediment package as well as the basement rocks. Other intrabasinal normal faults parallel to the basin margin are thought to have been active during the sedimentation (Ghosh 2002).

\subsection{Damodar valley basin-fill succession}

In Damodar valley, the Gondwana sediments overlie the Chhotanagpur Granite Gneiss Complex (CGC) showing broad concordance with the regional structure of the surrounding basement (Mazumdar 1988). Gondwana basins of the Damodar valley are presumed to extend also beneath the Cenozoic sediments of the Bengal basin (Uddin 1996) to the east. In Damodar valley basins, Phanerozoic sedimentation on Neoproterozoic basement was initiated with the deposition of Late Carboniferous Gondwana sediments. 
(a)

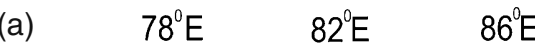

(b)

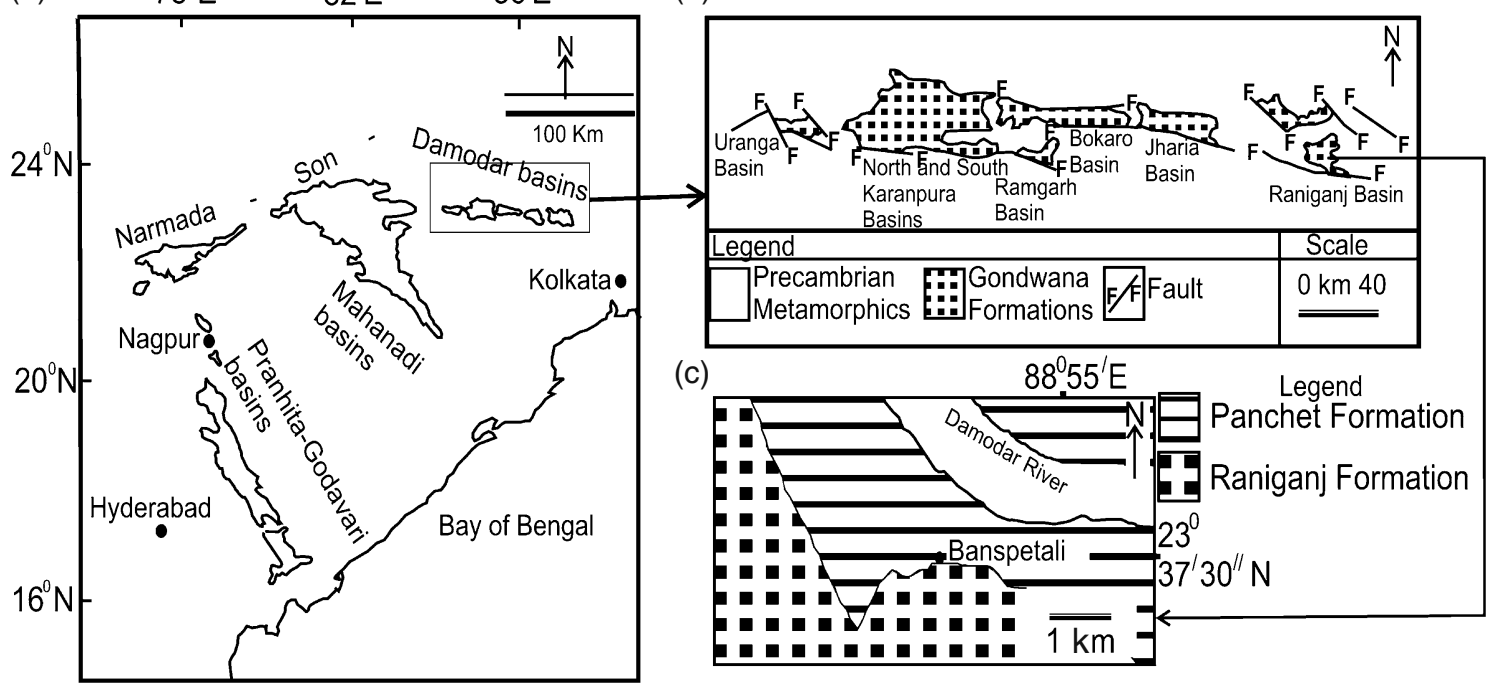

Figure 1. (a) Map of Gondwana basins of India (Bandyopadhyay 1999), (b) disposition of Raniganj basin in Damodar valley, and (c) geological map of the study area (Ghosh et al 1994).

Table 1. Stratigraphic succession of Gondwana sediments in Damodar valley (Raja Rao 1987).

\begin{tabular}{|c|c|c|c|}
\hline \multicolumn{2}{|l|}{ Age } & Group & Formation \\
\hline \multicolumn{2}{|c|}{ Lower Cretaceous } & Upper Gondwana & Lamprophyre and \\
\hline \multirow{3}{*}{ Jurassic } & Upper & & Sive \\
\hline & Middle & & Non-deposition \\
\hline & Lower & & \\
\hline \multirow[t]{3}{*}{ Triassic } & Upper Rhaetic & & Supra-Panchet Formation \\
\hline & Middle Noric & & Infra-Norian erosional surface \\
\hline & Lower Carnic & & Panchet Formation \\
\hline \multirow[t]{5}{*}{ Permian } & Upper & Lower Gondwana & Raniganj Formation \\
\hline & & & Barren Measures Formation \\
\hline & & & Barakar Formation \\
\hline & Lower & & Karharbari Formation \\
\hline & & & Talchir Formation \\
\hline
\end{tabular}

Precambrian Gneissic Basement of Chhotanagpur Granite Gneiss Complex

The general stratigraphy of the Gondwana sediments of the Damodar valley is presented in table 1 (after Raja Rao 1987). The Early Permian Talchir formation, the lowermost formation of the Lower Gondwana Group is glacigenic in origin. The lowermost Tillite Member of the Talchir formation unconformably overlies the Precambrian basement gneisses. These tillites are correlated with the Dwyka Tillite of South Africa and the Buckeye Tillite of Antarctica (Krishnan 1982).

The Talchir formation is overlain successively by Barakar formation, Barren Measure formation and Raniganj formation, from bottom to top. The Talchir formation has a conformable contact with the overlying sandstones of the Barakar formation which, in turn, pass conformably into the ironstone-shale of the Barren Measures formation. The Upper Permian Raniganj formation is the topmost unit of the Lower Gondwana Group.

The Panchet formation, which is the lowermost unit of the Upper Gondwana Group, in the Raniganj basin conformably overlies the Raniganj formation. The Panchet formation is overlain by the Supra Panchet formation which is composed of coarse sandstones and conglomerates. The Supra Panchet formation overlies the underlying formations as well as the crystalline basement rocks, with a pronounced unconformity (Bandyopadhyay et al 2002 and references therein).

Soft-sediment deformation structures are reported from both Upper and Lower Gondwana sediments (Ghosh and Mukhopadhyay 1986; 
Dasgupta 1998; 2008; Kundu and Goswami 2008). Kundu and Goswami (2008) interpreted softsediment deformation structures from a sandstonemudstone horizon within the Panchet formation (at a different study site and at a higher stratigraphic level) as seismites (sensu stricto).

\subsection{Lower Triassic Panchet formation}

The Panchet formation of Damodar valley is correlatable with the Maleri formation (PranhitaGodavari valley), Pali-Tiki formation (Son valley) and Panchmari-Denwa formation (Satpura basin) (Dutta 2002) and hence the Panchet formation and its equivalents are laterally persistent throughout the Gondwana Master-basin of the Indian peninsula.

Robinson (1970) described the Panchet formation as fluvio-lacustrine deposits and has divided the Panchet formation, having a generally coarsening upward sequence into three parts. The lower part is $50-100 \mathrm{~m}$ thick and is dominantly composed of green-coloured micaceous laminated siltstones with interbedded yellow-coloured, $0.5-4 \mathrm{~m}$ thick sandstones. The middle part is about $200 \mathrm{~m}$ thick, and is composed of red-coloured, laminated shaly siltstones with interbedded yellow coloured sandstones. The upper part is $300-400 \mathrm{~m}$ thick and is composed predominantly of grey-coloured sandstones with laminae of red-coloured mudstones. Interestingly pebbles of quartz, feldspars, clasts of mud and bone fragments are occasionally present in these rocks. Lystrosaurus fauna preserved in the Panchet formation indicates an overall fluvial-lacustrine paleoenvironment (Bandyopadhyay 1999).

\section{Description of soft-sediment deformation structures}

Various types of soft-sediment deformation structures: slumps, recumbent folds, convolute laminae, flame structures, water escape structures, sedimentary dykes, syn-sedimentary faults, dishand-pillar structures and pseudonodules are preserved within a heterolithic horizon (1.5-2.0 m thick and extending over about $9 \mathrm{~km}^{2}$ ) in the Panchet formation of the present study area (figure 1). The heterolithic horizon (figure 2) consisting of alternate layers of fine sandstones and mudstones suggests quiet water conditions for sedimentation (Collinson and Thompson 1982) and hence this horizon is posssibly a member of the lacustrine deposits of the generally fluviolacustrine Panchet formation (cf. Robinson 1970).

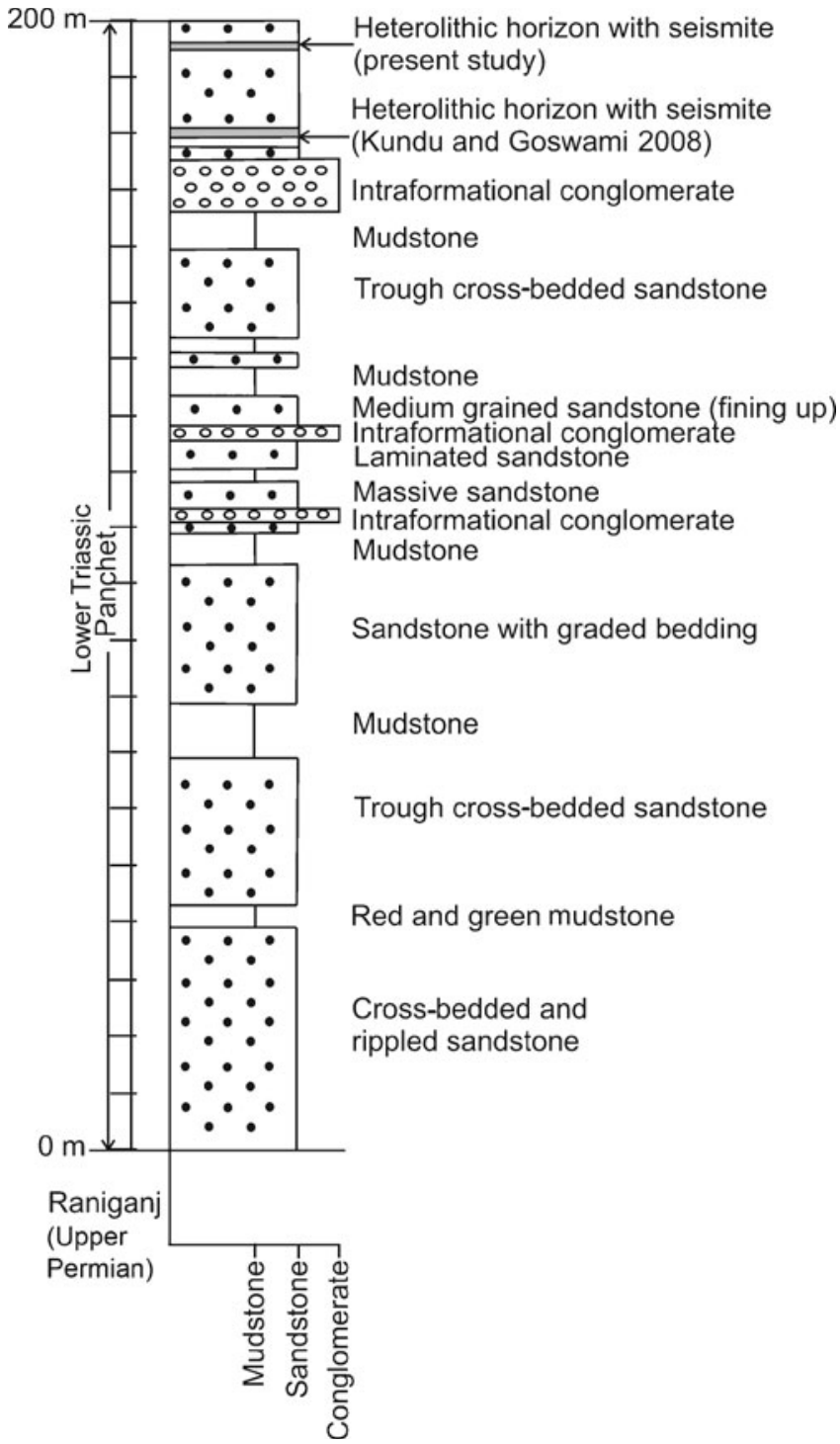

Figure 2. Stratigraphic section of the lower part of Panchet formation in the Banspetali Nullah section (Ghosh et al 1994) showing stratigraphic positions of the soft-sediment deformation structures.

The sandstone laminae of this heterolithic horizon are ochre yellow in colour, with variation from lemon-yellow to orange. The mudstone laminae are dark brown and grey-coloured. Sandstones are fine to very fine-grained, well-sorted and matrix-poor. These sandstones are classified mainly as arkoses and minor subarkoses.

\subsection{Slump folds}

\subsubsection{Description}

The observed slump folds in the heterolithic horizon (figure 3) are U-shaped, broad, hinged folds with sub-vertical axial planes (cf. Tasgin and 
Turkmen 2009). Fold axes are mostly horizontal to sub-horizontal and are oriented in the $\mathrm{N}-\mathrm{S}$ direction. The limbs are $30-35 \mathrm{~cm}$ long on average, and their terminations bend slightly towards each other. Much larger folds are also common. The limbs of one fold are often continuous with the adjacent slump folds and in many cases the limbs are breached (figure 3). In the latter cases, sand has been transported upwards through the gaps between the breached limbs. Within the same deformed heterolithic horizon a small-scale (15 cm long) normal fault has displaced sandstonemudstone laminae immediately overlying a slump fold (figure 3 ).

\subsubsection{Interpretation}

Down-slope movement of semi-consolidated sand layers over relatively more plastic layers under the action of gravity generally causes formation of
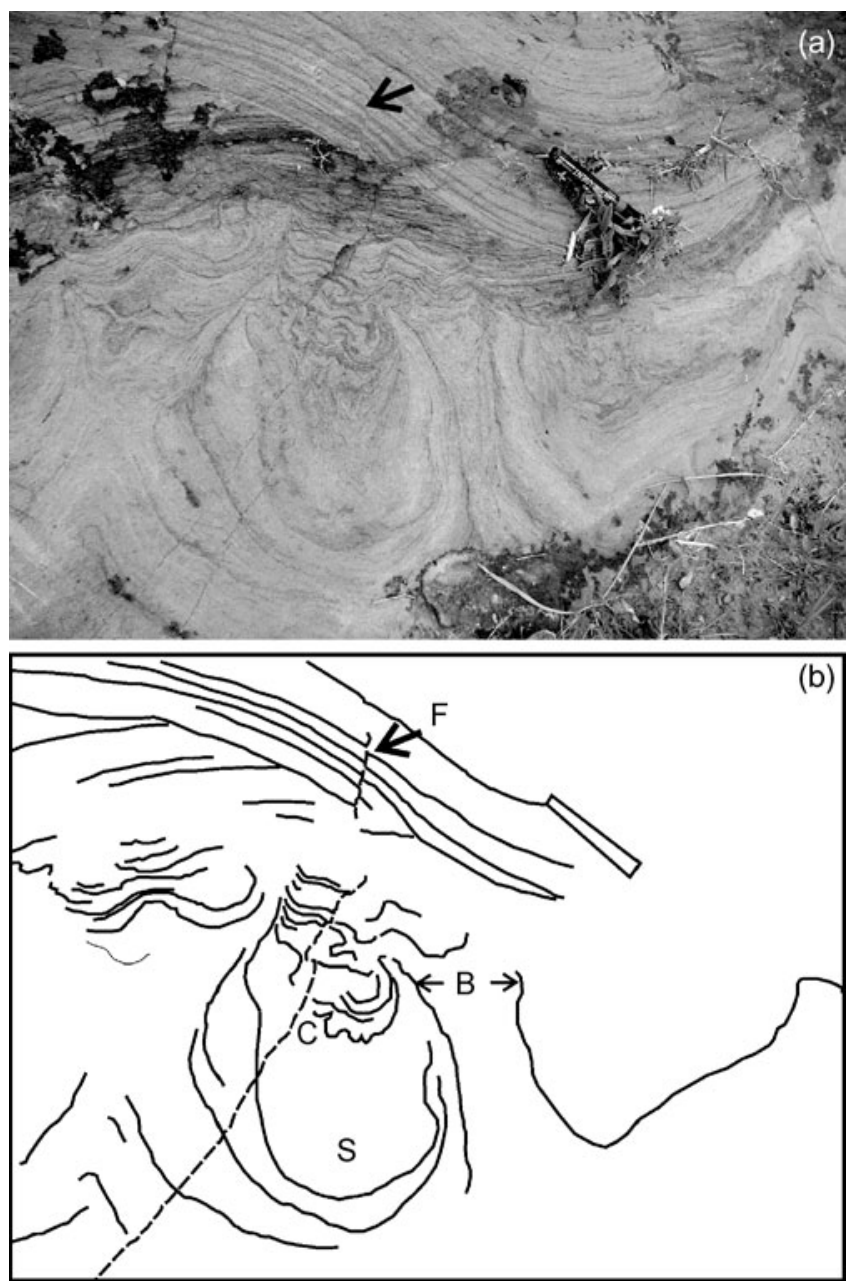

Figure 3. (a, b). Slump folds (S), convolute laminae (C) and small scale, layer-bound fault $(\mathrm{F})$. Breached portion of limbs of slump fold is at (B). Pocket knife $(7 \mathrm{~cm}$ long) for scale. slump folds. The down-slope movement may take place when the slope exceeds the angle of repose of the sediment (Mills 1983) or under the influence of large-scale water movements (Siegenthaler et al 1987). Lateral facies variations, a high proportion of fine-grained sediment and water content in sediments in glacial environments can also produce various soft-sediment deformation structures, including slump folds (Gruszka and Van Loon 2007). However, the sediments studied here were deposited in warm climatic conditions within a fluvial-lacustrine regime (Robinson 1970; Ghosh et al 1994), arguing against a glacigenic origin of these soft-sediment deformation structures.

Alternatively, slumping of sediment within a particular horizon may happen due to an earthquake (Shiki et al 2000; Schnellmann et al 2002; Spalluto et al 2007; Aboumaria et al 2009). The bedding planes in the study area are almost horizontal and post-lithification tectonic deformation structures of either microscopic or macroscopic (map) scale are not reported from these rocks. Hence it is likely that the original depositional attitudes of the bedding planes are preserved. In this context, slope-induced slumping under mere gravity pull appears to be an unlikely explanation for deformation, whereas according to Field et al (1982) earthquake-triggered slumping may take place on a gentle slope with a dip as low as $0.25^{\circ}$ where semi-consolidated strata may move en masse.

Incidentally, the slump folds in the studied section are in structural continuity with the associated convolutions, further supporting shockinduced mass flow in a plastic state. This type of flow and fluidization of sediment is likely to happen under the influence of earthquake shocks (Bhattacharya and Bandyopadhyay 1998). Thus in the present case, the fluidization might have been induced by earthquakes and the fluidized sediment that moved along a low pressure gradient provided space for overlying sediments to move down quickly to fill up the space. It is thought that escaping fluidized sediments generated a shear force at their flanks, which caused the folding of the slumped sediments, thus forming open-upwards slump folds. Hence the slump folds in the present study area are interpreted as probably having been seismically induced.

\subsection{Convolute laminae}

\subsubsection{Description}

Convolute laminae are present in the form of trains of small folds of alternating convex- and concaveup hinges, having unbroken dome-shaped crests 
and troughs (figure 3 ). The limbs are a few $\mathrm{mm}$ to about $1 \mathrm{~cm}$ thick and the fold amplitude is also a few centimetres. Fold axial planes are haphazardly oriented. In the concave- or convex-up folds the axial planes become steeply inclined to subvertical. The subvertical axial planes follow the axial planes of the larger slump folds which are present just below the convolutions. The convolutions die out upwards and form broad wavy laminae (figure 3).

\subsubsection{Interpretation}

Earthquakes or occasional pounding of channelbase sediments by large waves during fluvial processes may cause layer bound liquefaction and fluidization of unconsolidated sediment. Many authors (Middleton and Hampton 1973; Allen 1977; Chakraborty 1977; Cojan and Thiry 1992; Owen 1996; Rossetti 1999; Samaila et al 2006) suggest that convolution is related to fluidizationliquefaction events, and a concomitant expulsion of pore water. If the disturbance is due to $\mathrm{flu}$ vial processes then it is likely that deformation caused by liquefaction and fluidization would take place just below the sedimentation base. If laminae become convoluted due to this, then the upwardclosing convolutions would be commonly subjected to erosion by the water and sediment flow. Hence broken tops of convolution domes are commonly found if the deformation has a fluvial genesis. Convolutions of the Panchet Formation sedimentary rocks of the study area, on the contrary, have intact tops of the domes and hence were probably not related to fluvial processes (Selley et al 1963; Friend et al 1976; Chakraborty 1977). Furthermore the convolute laminae in the studied heterolitic horizon are sandwiched between undeformed strata, which indicates their seismic origin (Cojan and Thiry 1992). The Panchet convolutions change into slump folds in a downward direction, which suggests the continuity of the plastic behaviour of the sediment in the heterolithic horizon possibly during earthquake-induced deformation (Bhattacharya and Bandyopadhyay 1998).

\subsection{Recumbent folds}

\subsubsection{Description}

In the same heterolithic horizon, laterally about $15 \mathrm{~m}$ meters away from the slump structures, laminae are folded in sharp-hinged, tight recumbent folds (figure 4) closing opposite to the general palaeoflow direction as revealed from the crossstrata. Axial planes of the folds are almost par-

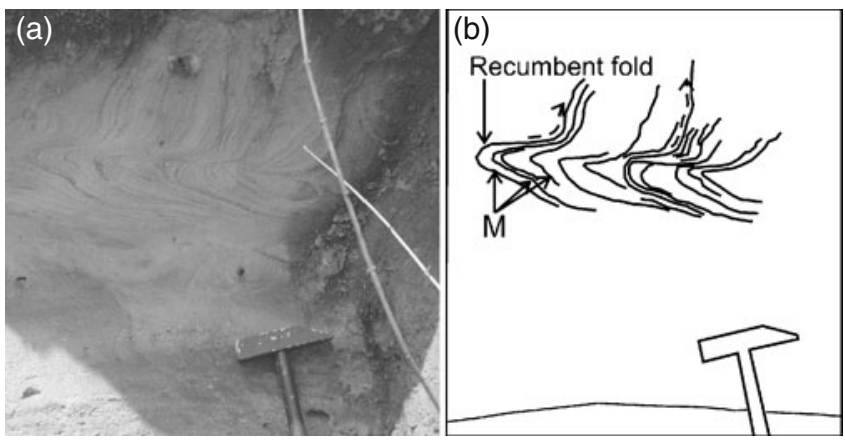

Figure 4. (a, b). Recumbent folded laminae. Note dextral minor (M) folds on lower limb and rotation of upper limb to a sub-vertical orientation (shown by broken arrows). Hammer head (15 cm long) for scale.

allel to the original bedding. Dextral minor folds are seen in the lower limbs when viewed from the southwest, whereas the upper limbs are rotated to become steeply dipping to the subvertical folds. These recumbent folds are in close association with upward pointing flame structures.

\subsubsection{Interpretation}

Shearing drag on liquefied sand may produce recumbent folds (Brenchley and Newall 1977). Allen and Banks (1972) and Owen (1995) interpreted recumbent folds in cross-stratified sediments as products of partial liquefaction associated with current drag triggered by earthquakes. Recumbent folds may develop in sandy sediments underlying mud layers, by earthquake shocks (Sims 1973). In the recumbent folds of the present study (figure 4) the upper limbs of the folds are themselves curved sub-vertically upwards while the lower limbs are asymmetrically folded; such complexity of the folds reflects repetitive pulses of deforming events in a plastic state (Bhattacharya and Bandyopadhyay 1998). Slope controlled deformation is unlikely to have occurred as the vergence of flame structures and the recumbent folds, preserved in a heterolithic horizon overlain and underlain by undeformed sedimentary beds, are at high angles to each other and thus earthquake-induced deformation can be envisaged (Upadhyay 2001).

\subsection{Flame structures}

\subsubsection{Description}

Flame structures in close proximity to recumbent folds are directed upward at a very high angle to the bedding. The flames are blunt at their tips and also crenulated (figure 5). The set of mudstone laminae that have taken the shape of the flames was 


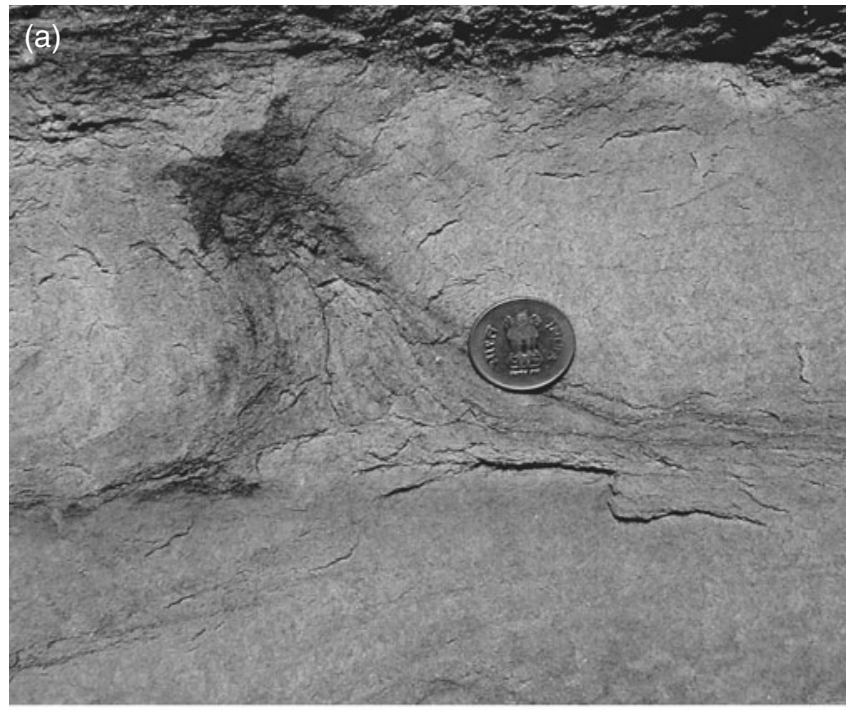

(b)

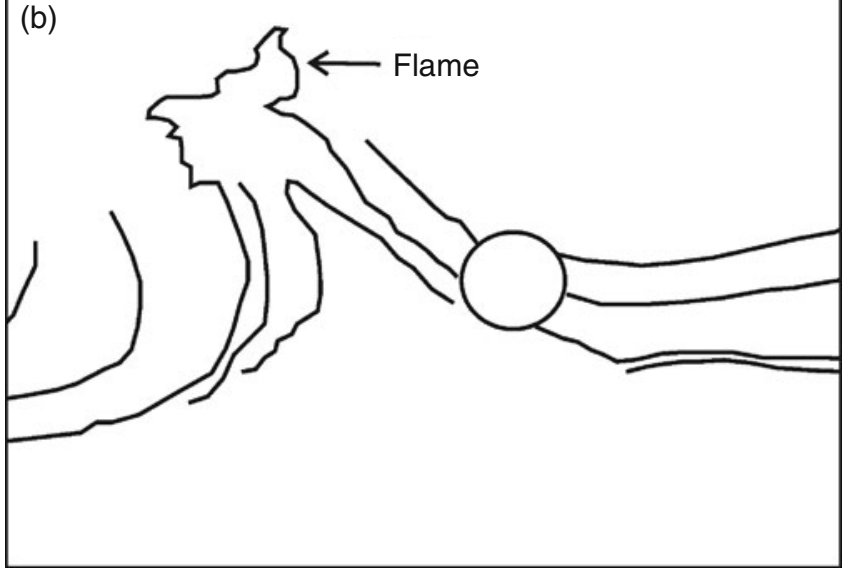

Figure 5. Steeply inclined flame structure with blunt and crenulated top. The adjacent laminae are bent upwards along the margin of the flame. Coin $(2.5 \mathrm{~cm}$ diameter $)$ for scale.

originally $2-5 \mathrm{~mm}$ thick, but at the flamed portions the thickness is $4-6 \mathrm{~cm}$. The curved laminae overlying the flamed mudstone layer follow the flame margin and take the shape of convex-upward folds above the apex of the flame.

\subsubsection{Interpretation}

Flame structures may form in heterolithic sediments due to density contrasts in distinct layers and induced, guided fluidization (Collinson and Thompson 1982); alternately, they can develop by differential dynamic viscosity in heterolithic deposits (Neuwerth et al 2006). Flame structures may form by one of the following processes:

- fluvial current drag (Kuenen and Menard 1952),

- action of pressure due to loading (Anketell et al 1970),

- slope controlled movement of sediment load (Brenchley and Newall 1977), and
- earthquake shock (Visher and Cunningham 1981; Sukhija et al 1999; Li et al 2008). According to Potter and Pettijohn (1977) vergence of flames is indicative of palaeoflow direction.

The near-vertical orientations of the flames in the Panchet sedimentary rocks argue against any genetic link with fluvial palaeoflow (see Dasgupta 1998). The flame structures in the diastrophically undeformed Panchet formation sediments thus attest to seismogenic fluidization (cf. Visher and Cunningham 1981; Li et al 2008).

\subsection{Breached sand laminae and water escape structures}

\subsubsection{Description}

Water escape structures are observed within the heterolithic deposits where very thin sand-mud interlaminations are present. The sand intrusions are mostly $2-4 \mathrm{~cm}$ wide; however, width varies along the length of the exposed deformed beds. Upward penetrations of sand through piercing of the original sand-mud laminae are indicated by upturned laminae at the points of breaching along the margins of the sand intrusions (figure 6). The upward flow is also clear from the dome shape of the upper bounding surface of the heterolithic horizon, just above the sandstone intrusions (figure 6).

\subsubsection{Interpretation}

Sediments can be liquefied by external shocks and then moving up through cracks which may form water escape structures (Collinson and Thompson 1982). Shear stress may be generated during water escape leading to disruption of overlying lamination; additionally, voids may form during dewatering within the sediment, which influence fluid drag that may balance gravitational forces (Tasgin and Turkmen 2009 and references therein). According to Lowe (1975), gravitational pull or overloading only play a subordinate role in the formation of water escape structures; consequently, seismic shocks are thought to be responsible for their formation (Moretti et al 1999). Hence the water escape structures breaching the sand-mud laminae in the present study can reasonably be interpreted as reflecting seismic shocks.

\subsection{Dish-and-pillar structures}

\subsubsection{Description}

Dish structures are present in the mudstone interlayers of the heterolithic beds. The dishes are 


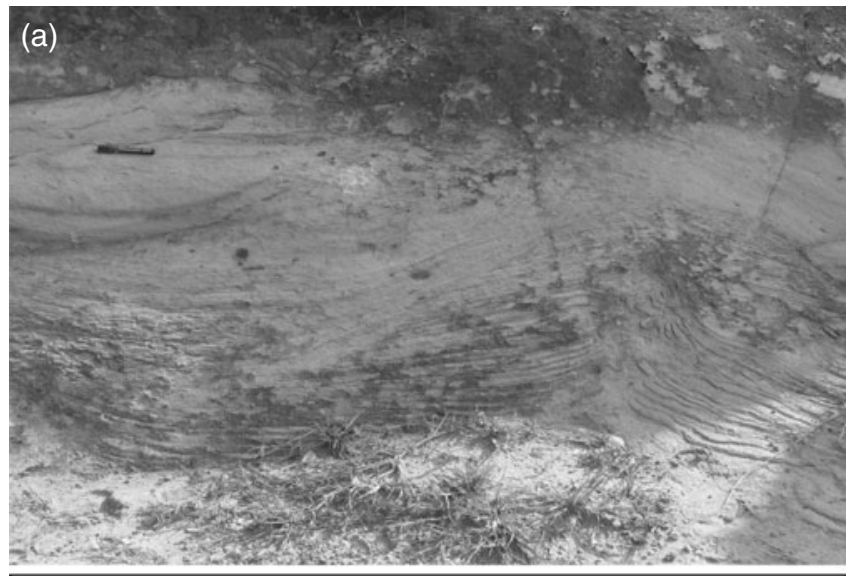

(b)

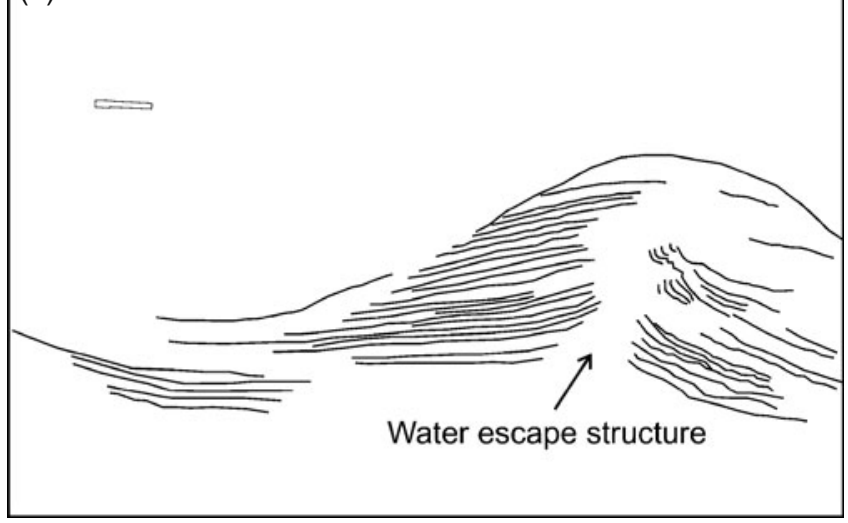

Figure 6. Breached laminae and water escape structure. Note the domal shape of the upper bounding surface to the breached laminae set, suggesting upward escape of water. Pen (14 cm long) for scale.

10-15 cm wide, concave-up thin laminar structures (figure 7). Vertical stacks of dishes are common; average thickness of stacks is $13 \mathrm{~cm}$. The stacks of dishes are intruded by steeply inclined to vertical sand pillars (figure 7). The bases of the pillars are at the same level as the bases of the vertical stacks of the dishes. Pillar-bases are 10-15 cm wide and their tops are almost always pointed. Some of the pillars stand higher than the top of the stack of adjacent dishes, but others do not.

\subsubsection{Interpretation}

Dish structures develop in clastic sediments by liquefaction (Hirono 2005). Dish-and-pillar structures are formed by flowage of particles or fluid transport by upward-directed dewatering (Hirono 2005). Lowe and LoPiccolo (1974) interpreted pillars as vertical water escape structures formed in response to pore pressure gradients during liquefaction and/or fluidization. Impermeable or semipermeable barriers within the sediment may cause the development of localized regions of high pore pressure in the fine-grained strata (Obermeier
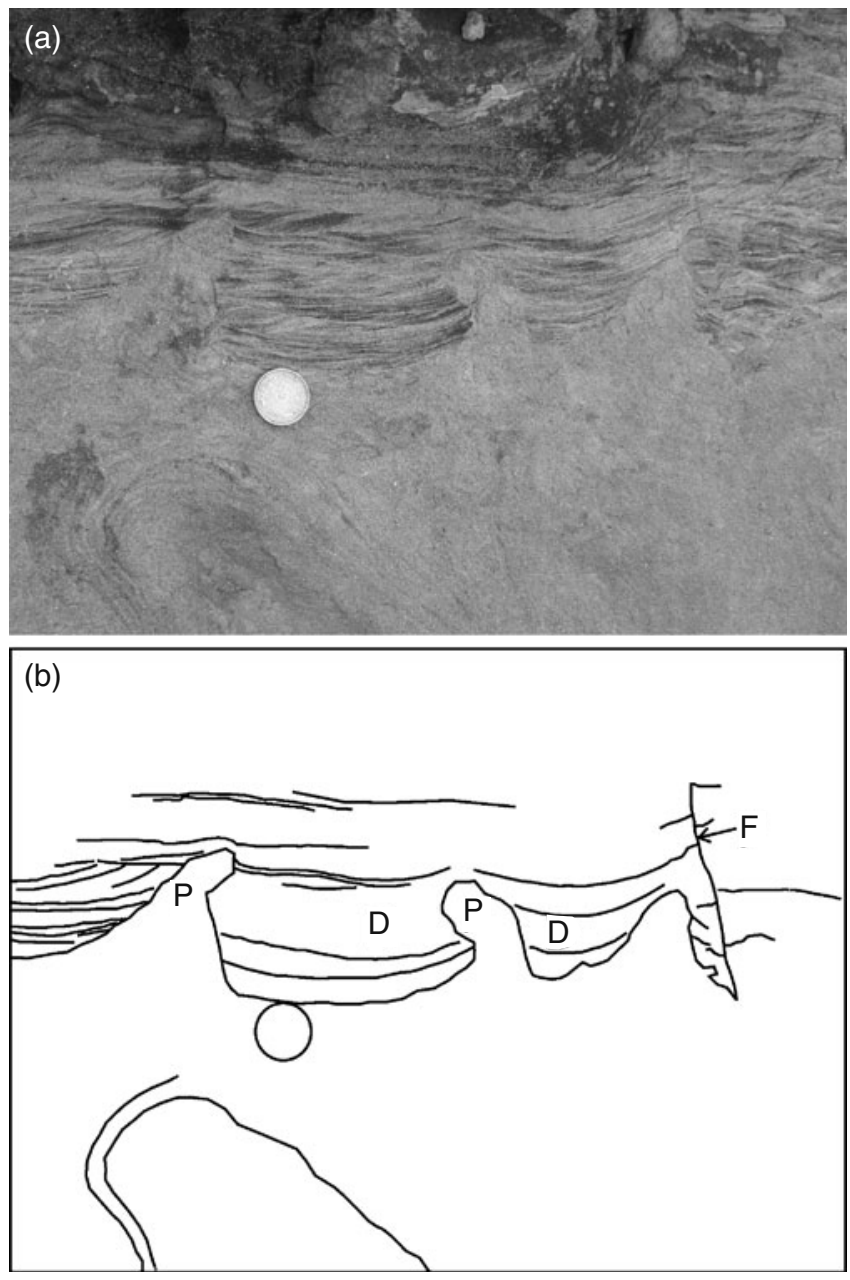

Figure 7. Dish (D) and pillar (P) structures in heterolithic bed. Note the presence of a layer-bound reverse fault $(\mathrm{F})$, which dislocates the dishes. Coin $(2.5 \mathrm{~cm})$ for scale.

1996). Fernandes et al (2007) and Foix et al (2008) suggested that such liquefaction and/or fluidization pillars are formed by seismic activity.

\subsection{Sandstone dykes}

\subsubsection{Description}

Sandstone dykes (figure 8) occurring adjacent to the slump folds (figure 3 ) are $20-30 \mathrm{~cm}$ high and $10-15 \mathrm{~cm}$ wide in the vertical section. Bases of the dykes are in the sandstones. These dykes occur in distinct intervals, pierce through the heterolithic laminae and sharply truncate the flat-lying undeformed overlying layer (figure 8).

\subsubsection{Interpretation}

Sandstone dykes preserved in the Panchet sedimentary rocks originate from sand-rich portions at the lower part of the heterolithic horizons, cut 


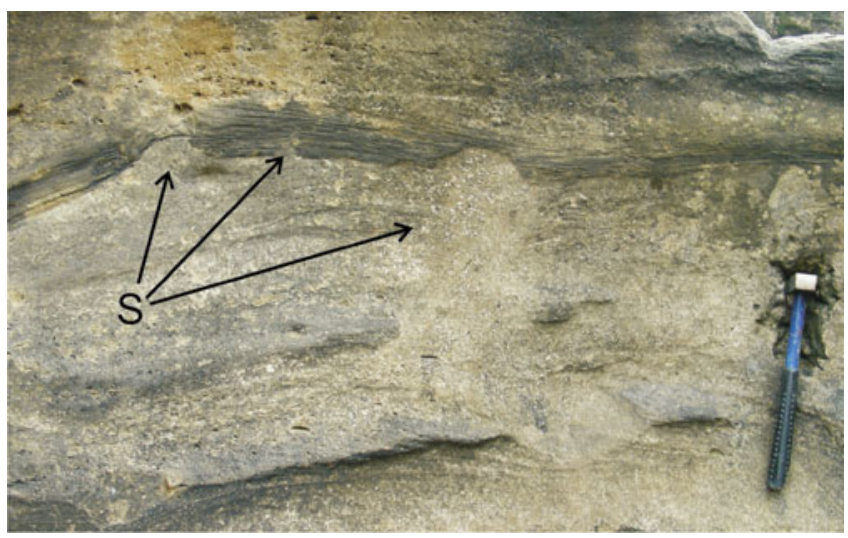

Figure 8. Sand dykes (S) intruding into overlying sediment layers. Hammer (45 cm long) for scale.

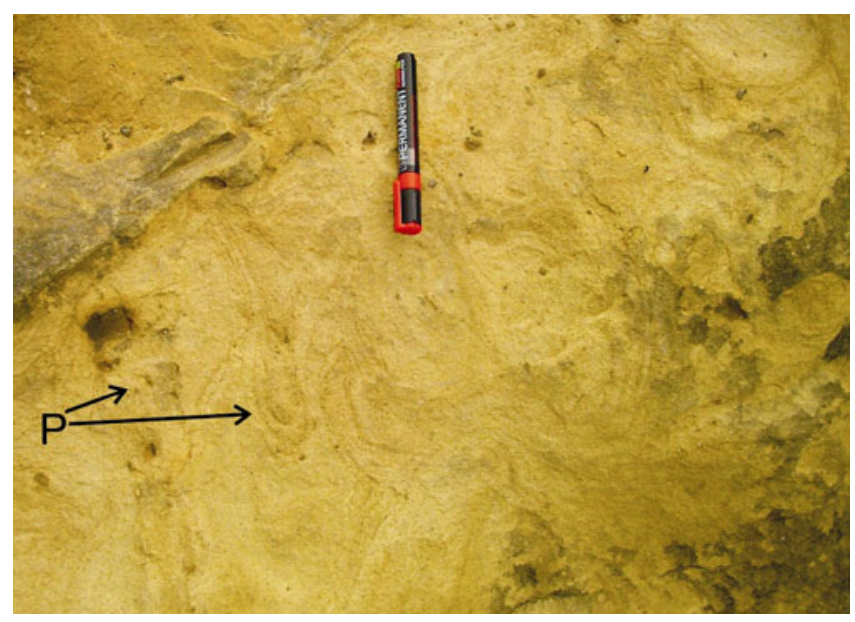

Figure 9. Pseudonodules $(\mathrm{P})$ with circular and elliptical cross-sections. Laminae are preserved in the pseudonodules. Pen $(14 \mathrm{~cm})$ for scale.

across the upper boundary of the deformed heterolithic horizon and intrude into the succeeding undeformed layer. This suggests that this deformational feature is certainly a meta-depositional one. It is believed that meta-depositional deformation rarely takes place by causes other than earthquake shocks (Mazumder et al 2006). Clastic dykes form during fluidization of sediment when the source layer of the dyke-forming sediment is more permeable than the overlying sediment layers (Bhattacharya and Bandyopadhyay 1998). Escape pipes are fractures generated by brittle failure and the fluidized sediment flows upward through these pipes (Owen 1995). The basal sand layer within which the root of the dyke is situated becomes liquefied (Sukhija et al 1999; Rodriguez-Pascua et al 2000 and references therein) and the fluid is separated from the sediment due to earthquake tremor (Montenat et al 2007). When pore water escape pipes are filled by fluidized sediments, 'sedimentary dykes' develop (Mazumder et al 2009). These dykes are highly inclined or nearly vertical at places within a horizontal set of strata and hence it can be assumed that these dykes were almost perpendicular to the propagation direction of the earthquake waves (Singh and Jain 2007).

\subsection{Pseudonodules}

\subsubsection{Description}

The pseudonodules occur as balls of circular and elliptical shape in the observed heterolithic deposits (figure 9). They are isolated in nature and are internally layered with contorted sandstone and mudstone laminae. Diameters of circular pseudnodules vary between 5 and $26 \mathrm{~cm}$. Long axes of the elliptical pseudnodules range between 10 and $20 \mathrm{~cm}$ and their short axes from 4 to $8 \mathrm{~cm}$. Pseudonodules are often present in structural continuity with the convolute laminations (figure 9).

\subsubsection{Interpretation}

Pseudonodules develop when the load-bearing strength of a sediment layer was lost due to liquefaction of the interbedded sand-mud layer (Kundu and Goswami 2008 and references therein). Pseudonodules are not diagnostic of seismic origin as they can be generated also by purely sedimentary processes (Moretti et al 1999). Kuenen (1965) experimentally showed that pseudonodules may form due to external shock. The detached nodules indicate sinking within a sand-mud layer which was in a liquefied state (Elliot 1965). Vertical sinking of the detached pseudonodules is reflected by the vertical orientation of long axes. This indicates that the affected and overlying sediments were possibly agitated (cf. Reineck and Singh 1980). Detached pseudonodules and associated folds indicate earthquake-induced deformation (RodríguezLópez et al 2007 and references therein). The association of pseudonodules with various other soft-sediment deformation structures within the same heterolithic horizon suggests their seismic origin (see Kundu and Goswami 2008).

\subsection{Faults}

\subsubsection{Description}

Small scale, layer-bound faults are observed at various locations within the heterolithic horizon. The faults have truncated and displaced deformed sand-mud laminae (figure 3). Conjugate sets of reverse faults, dipping towards each other, disrupt the dish structures (figure 7 ). These faults are 
15-25 cm long, with near vertical or steeply dipping fault planes. Both normal and reverse faults are present. All of these faults die out in upward and downward directions. Displacements along the faults are within a few $\mathrm{mm}$ to $1.2 \mathrm{~cm}$. Both graben and half-graben structures are commonly formed by small-scale faults.

\subsubsection{Interpretation}

The sedimentary layer hosting the faults is covered by undeformed sedimentary layers indicating syn-sedimentary origin of the faults. Seilacher (1969) first described such syn-sedimentary faults and also questioned their genetic relation to earthquakes (Seilacher 1984). However, according to Vanneste et al (1999) and Singh and Jain (2007) such faults may develop by earthquake shocks. Faults are a semi-brittle type of soft-sediment deformation formed by an increase in pore pressure in the sediment due to the instantaneous action of stress (Vanneste et al 1999 and references therein). Syn-sedimentary faults and other soft-sediment deformation structures are formed as a result of localized stresses induced by seismicity (Anand and Jain 1987; Miyata 1990). Hence faults in soft-sediment cannot be generated from downward slumping alone. Multiple phases of deformation in the soft state are indicated by the presence of layer-bound faults dislocating the dish structures in the Panchet formation. Hence repetitive occurrences of earthquakes can be envisaged.

\section{Discussion}

Penecontemporaneous deformation structures may be classified as syn-depositional, meta-depositional or post-depositional (Allen 1982; Owen 1995; Mazumder et al 2006). The occurrence of sandstone dykes suggests that they are meta-depositional soft-sediment deformation structures, which are observed to truncate overlying undeformed sediments. Earth-quake tremor is the most likely cause for meta-depositional deformation (Mazumder et al 2006).

In general, soft-sediment deformation structures maybe formed either by seismic processes or they may be gravity- and slope-controlled, or they can even form through the process of sedimentation itself (table 2). Sedimentation process-induced soft-sediment deformation structures do not always require high energy flow conditions. It depends on the kind of soft-sediment deformation structures that are produced. For instance, density contrastdriven pseudonodules do not require high energy flows but just density contrast between layers. The structures in this study cannot readily be related to sedimentary process-induced deformation associated with high-energy flows as this heterolithic sedimentary succession which bears the deformation features is overlain by a plane laminated undeformed sand-mud rich heterolithic horizon. An absence of high energy fluid flow over the deformed sediments in the presently studied Panchet formation heterolithic horizon is also supported by the unbroken tops of the observed convolutions. A possible genesis through gravity-induced slumping and concomitant liquefaction can also be ruled out because of the consistently horizontal orientation of the bedding surfaces of this unit, which was not affected by post-lithification tectonics. Plane laminated sand-mud interlayering is compatible with a quiet water lacustrine setting (Robinson 1970; cf. Bowman et al 2004). The horizontality of the strata and the absence of turbidite deposits indicate an absence of steep slope at the lake shore and in such an environment, slope-controlled gravity flow is unlikely (cf. Jones and Omoto 2000).

Soft-sediment deformation structures are regarded as seismites if:

- a spatially extensive single stratigraphic horizon preserves the structures,

- different types of structures are present together indicating synchronicity and instantaneity of deformation,

- the deformed horizon is underlain and overlain by undeformed strata,

- sedimentation occurs within an active tectonic setting, and

- similar structures have been described in published literature as seismites (Seilacher 1969; Sims 1975; Jones and Omoto 2000; Bose et al 2001; Wheeler 2002; Rodriguez-Lopez et al 2007).

The soft-sediment deformation structures in the present study are within a particular horizon that is sandwiched between beds without any softsediment deformation structure. The deformed horizon preserves various types of soft-sediment deformation structures distributed mostly laterally within the horizon, which has a known outcrop area of about $9 \mathrm{~km}^{2}$. Hence these structures are synchronous and were possibly formed by a single event that was most probably instantaneous. The geological setting, as discussed in section 2.1 of this paper, indicates that the continental basins of the Indian part of Gondwana, including the Raniganj basin, were tectonically active during PermianTriassic sedimentation, and there is direct evidence for episodic movement along basin boundary and intra-basinal faults during that time (Ghosh 2002). This indicates that recurrent syn-sedimenatry seismic activity occurred during the Permian-Triassic 


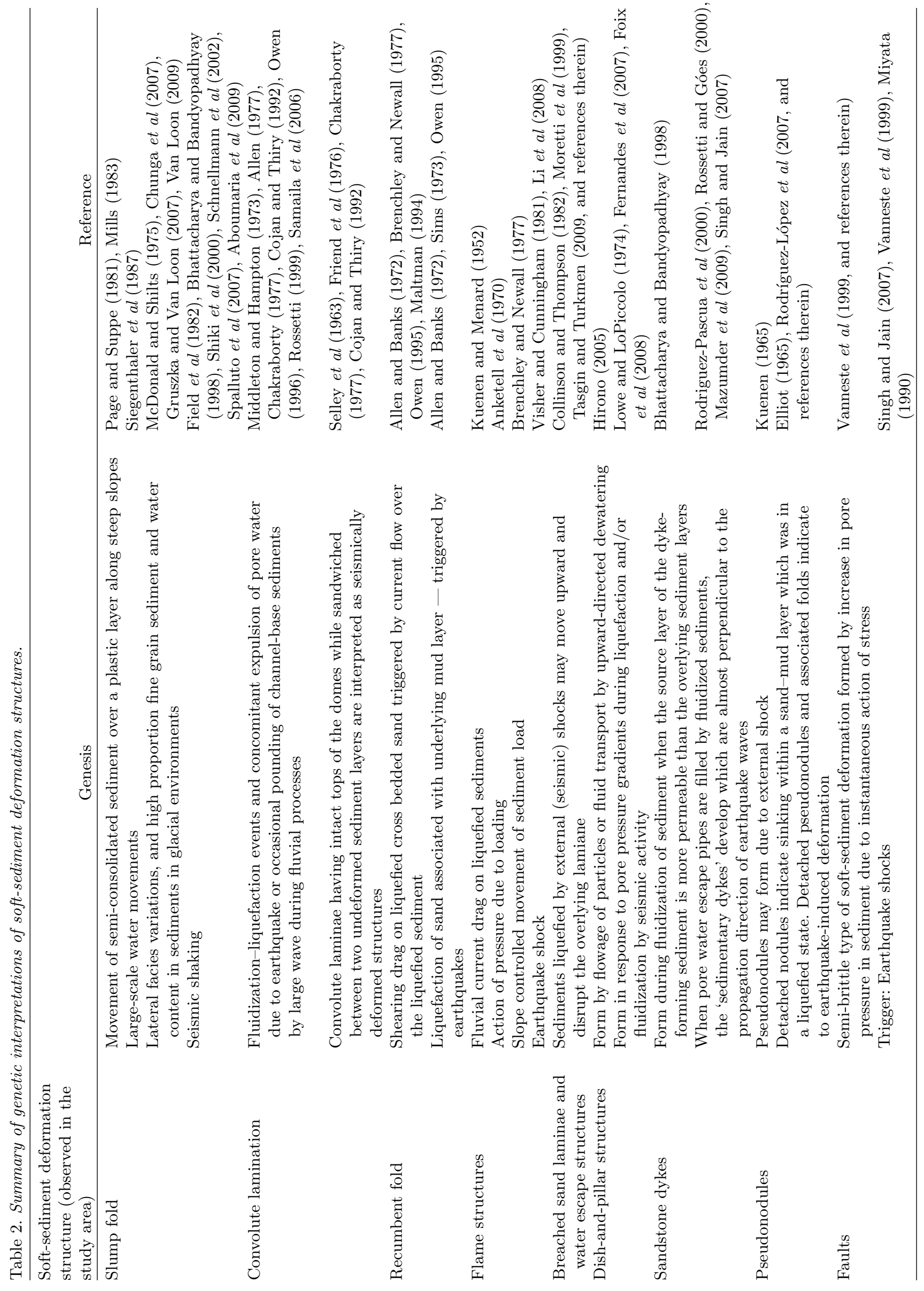


sedimentation. The reported seismites in another sandstone-mudstone horizon within the Panchet formation (Kundu and Goswami 2008) indicates recurrence of seismic events and supports this postulated episodic seismicity. The present study area lies within $5 \mathrm{~km}$ of the preserved basin margin (figure 1) and thus has a spatial association with areas where active tectonism may have occurred. Hence the soft-sediment deformation structures fulfill the established criteria to be strong candidates for seismic origin.

Formation of earthquake shock-generated softsediment deformation structures or 'seismites' (Seilacher 1984) is related to specific earthquake magnitudes by various workers (Tasgin and Turkmen 2009 and references therein). According to Seed and Idriss (1971), an earthquake having a magnitude as low as 2 to 3 on the Richter scale may suffice for the generation of seismites. However, much larger magnitudes are proposed by other workers: according to Marco and Agnon (1995), for liquefaction of unconsolidated sediments, the required magnitude is $>4.5$. Montenat et al (2007) and Morner (2005) proposed that a minimum magnitude of 5 is required for liquefaction and sediment deformation, while according to Sims (1975), it is $\geq 6$. Rodríguez-Pascua et al (2000) suggested that a magnitude of over 6.5 is required for the formation of pseudonodules. Kuribayashi and Tatsuoka (1975) and Obermeier et al (1991) proposed that a magnitude above 5 is necessary for liquefying sediments in continental scenarios. Scott and Price (1988) proposed that with earthquakes of magnitude $<5$, soft-sediment deformations develop within $4 \mathrm{~km}$ from the epicentre, and occur within $20 \mathrm{~km}$ thereof for an earthquake magnitude $>7$. The proximity (within $5 \mathrm{~km}$ ) of the studied Panchet formation sedimentary succession to the Raniganj basin boundary faults supports the possibility that earthquakes having a magnitude between 2 and 5 could have been enough for the formation of inferred seismites.

\section{Conclusions}

The Panchet formation sediments are postulated to have been affected by seismic activity during sedimentation and various soft-sediment deformation structures were formed. The earthquake(s) were most likely due to tectonic activity along basin marginal and intra-basinal faults, and the magnitude of the seismic events were enough to fluidize and liquefy the sediments and thus to produce various soft-sediment deformation structures, within several kilometres of the faults.

\section{Acknowledgements}

The authors gratefully acknowledge Dr Juan Pedro Rodríguez-López and Dr A K Jain for their detailed reviews and constructive suggestions. The Principal, Asutosh College and the Head of the Department of Geology, University of Calcutta are gratefully thanked for providing infrastructural facilities. We thank Dr K Ganguly for data support.

\section{References}

Aboumaria K, Zaghloul M N, Battaglia M, Loiacono F, Puglisi D and Aberkan M 2009 Sedimentary processes and provenance of Quaternary marine formations from the Tangier Peninsula (Northern Rif, Morocco); J. African Earth Sci. 55(1-2) 10-35.

Allen J R L 1977 The possible mechanics of convolute lamination in graded beds; J. Geol. Soc. 134 19-31.

Allen J R L 1982 Sedimentary Structures - Their Character and Physical Basis (Amsterdam: Elsevier) 2663.

Allen J R L and Banks N L 1972 An interpretation and analysis of recumbent folded deformed cross-bedding; Sedimentology 19 257-283.

Anand A and Jain A K 1987 Earthquakes and deformational structures (seismites) in Holocene sediments from the Himalayan-Andaman Arc, India; Tectonophys. 133 105-120.

Anketell J M, Cega J and Duyski S 1970 On the deformational structures in systems with reversed density gradients; Rocznik Polskiego Towarzystwa Geologicznego $\mathbf{4 0}$ $3-30$.

Bandyopadhyay S 1999 Gondwana vertebrate faunas of India; Proc. Indian Nat. Sci. Acad. 65A(3) 285-313.

Bandyopadhyay S, Roy Chowdhury T K and Sengupta D P 2002 Taphonomy of some Gondwana vertebrate assemblages of India; Sedim. Geol. 147 219-245.

Bhattacharya H N and Bandyopadhaya S 1998 Seismites in a Proterozoic tidal succession, Singhbhum, Bihar, India; Sedim. Geol. 119 239-252.

Biswas S K 1999 A review on the evolution of rift basins in India during Gondwana with special reference to western Indian basins and their hydrocarbon prospects; In: Gondwana assembly: New issues and perspectives (eds) Sahni A and Loyal R S, Proc. Indian Nat. Sci. Acad. Spec. Issue pp. 261-283.

Bose P K, Sarkar S, Chakraborty S and Banerjee S 2001 Overview of the Meso- to Neoproterozoic evolution of the Vindhyan basin, central India; Sedim. Geol. 141 395-419.

Bowman D, Korjenkov A and Porat N 2004 Late-Pleistocene seismites from Lake Issyk-Kul, the Tienshan range, Kyrghyzstan; Sedim. Geol. 163 211-228.

Brenchley P J and Newall G 1977 The significance of contorted bedding in upper Ordovician sediments of the Oslo region, Norway; J. Sedim. Petrol. 44 819-833.

Chakraborty A 1977 Upward flow and convolute lamination; Senckenbergiana Marit 9 285-305.

Chakraborty C and Ghosh S K 2005 Pull-apart origin of the Satpura Gondwana basin, central India; J. Earth Syst. Sci. 114(3) 259-273.

Chunga K, Livio F, Michetti A M and Serva L 2007 Synsedimentary deformation of Pleistocene glaciolacustrine deposits in the Albese con Cassano Area (Southern 
Alps, Northern Italy), and possible implications for paleoseismicity; Sedim. Geol. 196 59-80.

Cojan I and Thiry M 1992 Seismically induced deformation structures in Oligocene shallow-marine and eolian coastal sands (Paris Basin); Tectonophys. 206 79-89.

Collinson J D and Thompson D B 1982 Sedimentary Structures (London: Allen and Unwin) p. 194.

Dasgupta P 1998 Recumbent flame structures in the Lower Gondwana rocks of the Jharia Basin, India - A plausible origin; Sedim. Geol. 119 253-361.

Dasgupta P 2008 Experimental decipherment of the softsediment deformation observed in the upper part of the Talchir Formation (Lower Permian), Jharia Basin, India; Sedim. Geol. 205 100-110.

Dutta P 2002 Gondwana lithostratigraphy of Peninsular India; Gondwana Res. (Gondwana Newsletter Section) 5(2) 540-553.

Elliot R E 1965 A classification of subaqueous sedimentary structures based on rheological and kinematical parameters; Sedimentology 5 193-209.

Fernandes L A, de Castro A B and Basilici G 2007 Seismites in continental sand sea deposits of the Late Cretaceous Caiuá Desert, Bauru Basin, Brazil; Sedim. Geol. 199 51-64.

Field M E, Gardner J V, Jennings A E and Edwards B D 1982 Earthquake-induced sediment failures on a $0.25^{\circ}$ slope, Klamath river delta, California; Geology 10 $542-546$.

Friend P F, Alexander-Marrack P D, Nicholson J and Yeats A K 1976 Devonian sediments of the east Greenland II: Sedimentary structures and fossils; Meddeleser em Gronland 206(2) 1-91.

Foix N, Paredes J M and Giacosa R E 2008 Paleoearthquakes in passive-margin settings, an example from the Paleocene of the Golfo San Jorge Basin, Argentina; Sedim. Geol. 205 67-78.

Gee E R 1932 Geology and coal resources of Raniganj; Geol. Surv. India Memoir 61 1-343.

Ghosh S C 2002 The Raniganj Coal Basin: An example of an Indian Gondwana rift; Sedim. Geol. 147 155-176.

Ghosh S C, Nandi A and Ahmed G 1994 Study of PermoTriassic boundary in Gondwana sequence of Raniganj basin, India; Proceedings, 9th International Gondwana Symposium, Hyderabad, India (New Delhi: Oxford and IBH Publishers) pp. 179-193.

Ghosh S K and Mukhopadhyay A 1986 Soft-sediment recumbent folding in a slump-generated bed in Jharia Basin, eastern India; J. Geol. Soc. India 27 194-201.

Gibbs A D 1984 Structural evolution of extensional basin margins; J. Geol. Soc. 141 609-620.

Gruszka B and Van Loon A J (Tom) 2007 Pleistocene glaciolacustrine breccias of seismic origin in an active graben (central Poland); In: Quaternary Geology - Bridging the gap between East and West (eds) Gruszka B, Van Loon A J (Tom) and Zieliński T, Sedim. Geol. Spec. Issue 193 93-104.

Guccione M J 2005 Late Pleistocene and Holocene paleoseismology of an intraplate seismic zone in a large alluvial valley, the new Madrid seismic zone, Central USA; Tectonophys. 408 237-264.

Hirono T 2005 The role of dewatering in the progressive deformation of a sandy accretionary wedge: Constraints from direct imagings of fluid flow and void structure; Tectonophys. 397 261-280.

Jones A P and Omoto K 2000 Towards establishing criteria for identifying trigger mechanisms for soft sediment deformation: A case study of Late Pleistocene lacustrine sands and clays, Onikobe and Nakayamadaira Basins, northeastern Japan; Sedimentology 47 1211-1226.
Krishnan M S 1982 Geology of India and Burma, 6th edn. (New Delhi: CBS Publishers) p. 536.

Kuenen $\mathrm{Ph} \mathrm{H} 1965$ Value of experiments in geology; Geologie en Mijnbouw 44 22-36.

Kuenen Ph H and Menard H W 1952 Turbidity currents, graded and non-graded deposits; J. Sedim. Petrol. 22 83-96.

Kundu A and Goswami B 2008 A note on seismic evidences during the sedimentation of Panchet Formation, Damodar Basin, Eastern India: Banspetali Nullah Revisited; J. Geol. Soc. India 72 400-404.

Kuribayashi E and Tatsuoka F 1975 Brief review of liquefaction during earthquakes in Japan; Soil and Foundations 15(4) 81-92.

Li S, Du Y, Zhang Z and Wu J 2008 Earthquake-related soft-sediment deformation structures in Palaeogene on the continental shelf of the East China Sea; Front. Earth Sci. China 2(2) 177-186.

Lowe D R 1975 Water escape structures in coarse-grained sediments; Sedimentology 22 157-204.

Lowe D R and LoPiccolo R D 1974 Characteristics and origins of dish and pillar structures; J. Sedim. Petrol. 44 484-501.

Maltman A 1994 Introduction and overview; In: The Geological Deformation of Sediments (ed.) Maltman A (London: Chapman \& Hall) pp. 1-36.

Marco S and Agnon A 1995 Prehistoric earthquake deformations near Massada, Dead Sea Graben; Geology 23 695-698.

Mazumdar S K 1988 Crustal evolution of the Chotanagpur gneissic complex and the mica belt of Bihar; In: Precambrian of the Eastern Indian Shield (ed.) Mukhopadhyay D, Geol. Soc. India Memoir 8 49-83.

Mazumder R, Van Loon A J and Arima M 2006 Softsediment deformation structures in Earth's oldest seismites; Sedim. Geol. 186 19-29.

Mazumder R, Rodríguez-López J P, Arima M and Van Loon A J 2009 Palaeoproterozoic seismites (fine-grained facies of the Chaibasa Fm., E India) and their soft-sediment deformation structures; In: Palaeoproterozoic supercontinents and global evolution (eds) Reddy S, Mazumder R, Evans D and Collins A, Geol. Soc. Spec. Publ. 323 301-318.

McDonald B and Shilts W W 1975 Interpretation of faults in glaciofluvial sediments; In: Glaciofluvial and glaciolacustrine sedimentation (eds) Jopling A and McDonald B, Society of Economic Paleontologists and Mineralogists Special Publication 23 123-131.

Middleton G V and Hampton M A 1973 Sediment gravity flows: Mechanics of flow and deposition; Society of Economic Paleontologists and Mineralogists, Tulsa Oklahoma, Short Course Notes, p. 38.

Mills P C 1983 Genesis and diagnostic value of soft-sediment deformation structures - A review; Sedim. Geol. 35 83-104.

Mitra N D 1994 Tensile resurgence along fossil sutures: A hypothesis on the evolution of Gondwana basins of peninsular India; Abstracts of Proceedings, 2nd Symposium on Petroliferous basins of India (Dehradun: KDMIPE Publishers) pp. 55-62.

Mishra D C, Chandra Sekhar D V, Venkata Raju D Ch and Vijay Kumar V 1999 Crustal structure based on gravity-magnetic modelling constrained from seismic studies under Lambert Rift, Antarctica and Godavari and Mahanadi rifts, India and their interrelationship; Earth Planet. Sci. Lett. 172 287-300.

Miyata T 1990 Slump strain indicative of paleoslope in Cretaceous Izumi sedimentary basin along Median tectonic line, southwest Japan; Geology 18(5) 392-394. 
Montenat C, Barrier P, Ott d'Estevou P and Hibsch C 2007 Seismites: An attempt at critical analysis and classification; Sedim. Geol. 196 5-30.

Moretti M, Alfaro P, Caselles O and Canas J A 1999 Modelling seismites with a digital shaking table; Tectonophys. $304369-383$.

Mörner N-A 2005 An interpretation and catalogue of paleoseismicity in Sweden; Tectonophys. 408 265-307.

Narain H 1994 Gondwana palaeomagnetism and crustal structures; In: Proceedings, 9th International Gondwana Symposium, Hyderabad, India (New Delhi: Oxford and IBH Publishers) pp. 951-952.

Narula P L, Acharyya S K and Banerjee J 2000 Seismotectonic atlas of India and its environs; Geol. Surv. India Spec. Publ. 87 1-87.

Neuwerth R, Suter F, Guzman C A and Gorin G E 2006 Soft-sediment deformation in a tectonically active area: The Plio-Pleistocene Zarzal Formation in the Cauca Valley (Western Colombia); Sedim. Geol. 186 67-88.

Obermeier S F 1996 Use of liquefaction-induced features for paleoseismic analysis; Eng. Geol. 44 1-76.

Obermeier S F and nine others 1991 Evidence of strong earthquake shaking in the lower Wabash Valley from prehistoric liquefaction features; Science 251 10611063.

Owen G 1995 Soft sediment deformation in Upper Proterozoic Torridonian Sandstones (Applecross Formation) at Torridon, Northwest Scotland; J. Sedim. Res. A65 495-504.

Owen G 1996 Experimental soft-sediment deformation: Structures formed by liquefaction of unconsolidated sands and some ancient examples; Sedimentology $\mathbf{4 3}$ 279-293.

Page B M and Suppe J 1981 The Pliocene Lichi Melange of Taiwan: Its plate-tectonic and olistostromal origin; $\mathrm{Am}$. J. Sci. 281 193-227.

Potter P E and Pettijohn F J 1977 Paleocurrents and basin analysis; 2nd edn. (Berlin: Springer-Verlag) p. 413.

Raja Rao C S (ed.) 1987 Coalfields of India; Bull. Geol. Surv. India A IV(45) Part I, p. 336.

Ramanamurthy B V and Parthasarathy E V R 1988 On the evolution of the Godavari Gondwana Graben, based on LANDSAT Imagery interpretation; J. Geol. Soc. India 32 417-425.

Reineck H E and Singh I B 1980 Depositional sedimentary environments (Berlin-Heideberg-New York: SpringerVerlag) p. 439.

Ricci Lucchi F 1995 Sedimentographica. A photographic atlas of sedimentary structures; 2nd edn. (New York: Columbia University Press) p. 255.

Robinson P L 1970 The Indian Gondwana formations a review; In: Proceedings, First International Symposium on Gondwana Stratigraphy, I.U.G.S., Buenos Aires, South America, pp. 201-268.

Rodríguez-López J P, Meléndez N, Soria A R, Carlos L L and Van Loon A J 2007 Lateral variability of ancient seismites related to differences in sedimentary facies (the synrift Escucha Formation, mid-Cretaceous, eastern Spain); Sedim. Geol. 201 461-484.

Rodríguez-Pascua M A, Calvo J P, De Vicente G and Gómez-Gras D 2000 Soft-sediment deformation structures interpreted as seismites in lacustrine sediments of the Prebetic Zone, SE Spain, and their potential use as indicators of earthquake magnitudes during the Late Miocene; Sedim. Geol. 135 117-135.

Rossetti D F 1999 Soft sediment deformation structures in late Albian to Cenomanian deposits, Sao Luis Basin, northern Brazil: Evidence for palaeoseismicity; Sedimentology 46 1065-1081.

Rossetti D F and Góes A M 2000 Deciphering the sedimentological imprint of paleoseismic events: An example from the Aptian Codó Formation, northern Brazil; Sedim. Geol. 135 137-156.

Samaila N K, Abubakar M B, Dike E F C and Obaje N G 2006 Description of soft-sediment deformation structures in the Cretaceous Bima Sandstone from the Yola Arm, Upper Benue Trough, Northeastern Nigeria; J. African Earth Sci. 44 66-74.

Schnellmann M, Anselmetti F S, Giardini D, Mckenzie J A and Ward S N 2002 Prehistoric earthquake history revealed by lacustrine slump deposits; Geology 30(12) 1131-1134.

Scott B and Price S 1988 Earthquake-induced structures in young sediments; Tectonophys. 147 165-170.

Seed H B and Idriss I M 1971 Simplified procedure for evaluating soil liquefaction potential; J. Soil Mech. Found. Div., ASCE 97(SM9) 1249-1273.

Seilacher A 1969 Fault-graded beds interpreted as seismites; Sedimentology 13 155-159.

Seilacher A 1984 Sedimentary structures tentatively attributed to seismic events; Marine Geol. 55 1-12.

Selley R C, Shearman D J, Sutton J and Watson J 1963 Some underwater disturbances in the Torridonian of Skye and Raasay; Geol. Mag. 100 224-243.

Seth A, Sarkar S and Bose P K 1990 Syn-sedimentary seismic activity in an immature passive margin basin (Lower Member of the Katrol Formation, Upper Jurassic, Kutch, India); Sedim. Geol. 68 279-291.

Siegenthaler C, Finger W, Kelts K and Wang S 1987 Earthquake and seiche deposits in Lake Lucerne, Switzerland; Eclogae Geologicae Helvetica 80 241-260.

Sims J D 1973 Earthquake-induced structures in sediments of Van Norman Lake, San Fernando, California; Science 182 161-163.

Sims J D 1975 Determining earthquake recurrence intervals from deformational structures in young lacustrine sediments; Tectonophys. 29 144-152.

Singh S and Jain A K 2007 Liquefaction and fluidization of lacustrine deposits from Lahaul-Spiti and Ladakh Himalaya: Geological evidences of paleoseismicity along active fault zone; Sedim. Geol. 196 47-57.

Shiki T, Kumon F, Inouchi Y, Kontani Y, Sakamoto T, Tateishi M, Matsubara H and Fukuyama K 2000 Sedimentary features of the seismo-turbidites, Lake Biwa, Japan; Sedim. Geol. 135 37-50.

Spalluto L, Moretti M, Festa V and Tropeano M 2007 Seismically-induced slumps in Lower-Maastrichtian peritidal carbonates of the Apulian Platform (southern Italy); Sedim. Geol. 196 81-98.

Sukhija B S, Rao M N, Reddy D V, Nagabhushanam P, Hussain S, Chadha R K and Gupta H K 1999 Timing and return period of major palaeoseismic events in the Shillong Plateau, India; Tectonophys. 308 53-65.

Sukhija B S, Poornachandra Rao G V S, Reddy D V, Kumar D, Mallikharjuna Rao J, Lakshmi K J P and Srinivasa Rao B 2003 Palaeomagnetism of palaeoliquefaction: An aid to palaeoseismology; Curr. Sci. 84(3) 280-283.

Tasgin C K and Turkmen I 2009 Analysis of soft-sediment deformation structures in Neogene fluvio-lacustrine deposits of Çaybağı Formation, Eastern Turkey; Sedim. Geol. 218 16-30.

Tewari R C and Casshyap S M 1996 Mesozoic tectonic events including rifting in Peninsular India, and their bearing on Gondwana stratigraphy, and sedimentation; In: Proceedings, 9th International Gondwana Symposium 
Hyderabad, India (New Delhi: Oxford and IBH Publishers) pp. 865-880.

Uddin M N 1996 Structure and sedimentation in the Gondwana basins of Bangladesh; In: Proceedings, 9th International Gondwana Symposium, Hyderabad (New Delhi: Oxford and IBH Publishers) pp. 805-819.

Upadhyay R 2001 Seismically-induced soft-sediment deformational structures around Khalsar in the Shyok Valley, northern Ladakh and eastern Karakoram, India; Curr. Sci. 81 600-604.

Vanneste K, Meghraoui M and Camelbeeck T 1999 Late Quaternary earthquake-related soft-sediment deformation along the Belgian portion of the Feldbiss Fault, Lower Rhine Graben system; Tectonophys. 309 57-79.
Van Loon A J (Tom) 2009 Soft-sediment deformation structures in siliciclastic sediments: An overview; Geologos 15(1) 3-55.

Veevers J J and Tewari R C 1995 Gondwana master basin of peninsular India between Tethys and the interior of the Gondwanaland province of Pangea; Geol. Soc. Am. Memoir 187 1-73.

Visher G S and Cunningham R D 1981 Convolute laminations - a theoretical analysis: Example of a Pennsylvanian sandstone; Sedim. Geol. 28 175-188.

Wheeler R L 2002 Distinguishing seismic from nonseismic soft-sediment structures: Criteria from seismic-hazard analysis; In: Ancient Seismites (eds) Ettensohn F R, Rast N and Brett C E, Geol. Soc. Am. Spec. Paper 359 1-11.

MS received 5 November 2009; revised 5 May 2010; accepted 12 September 2010 